\title{
O direito ao conhecimento da origem das ligações telefônicas pelo destinatário, independentemente de qualquer restrição ou autorização judicial
}

Leonir Batisti ${ }^{1}$

\section{Resumo}

\begin{abstract}
A Constituição Federal estabelece como direito e garantia fundamental a inviolabilidade de dados e comunicações telefônicas. Permite exceção dessa inviolabilidade, se houver autorização judicial e a autorização se destinar a investigações criminais ou instrução processual penal. A normativa constitucional tem servido para as empresas de comunicação telefônica exigirem ordem judicial para informar dados e registros telefônicos aos destinatários de ameças, extorsões ou mesmo perturbações de outra ordem. Contudo, não há qualquer fundamentação ou razoabilidade em tal interpretação, pois, o destinatário de comunicação tem direito de conhecer os dados de ligações feitas para seu terminal telefônico sem qualquer restrição, pois a hipótese não é abrangida pela inviolabilidade.
\end{abstract}

Palavras-Chave: Dados telefônicos; Comunicações telefônicas; Sigilo; Inviolabilidade.

\section{Introdução}

O uso do telefone difundiu-se de modo bem acentuado no Brasil. A alteração do modelo centralizado e estatal para o modelo privado e de concorrência serve para explicar essa difusão. Havia em dezembro de 200249.234 .600 telefones fixos e 34.881 .000 telefones celulares. A meta prevista para dezembro de 2005 é de 58 milhões de telefones fixos e 58 milhões de telefone celulares ${ }^{2}$.

A questão é que esta difusão trouxe consigo vários hábitos e situações. Constata-se hoje uma irrefreável utilização do telefone como meio de crime, principalmente extorsão $e$ ameaça.

Tem acontecido que as companhias de telecomunicações recusam-se a fornecer às vítimas a origem desses telefonemas, implicando em desasossego destas.

1 Promotor de Justiça - Londrina - Paraná.

Dados do Ministério das Comunicações, acesso em 12-set-2005 (www.mc.gov.br/telecom/metas). 
O OBJETIVO do presente estudo é apontar o quadro em que se assenta o problema do acesso a dados e registros telefônicos e apontar uma interpretação de regras jurídicas que indique o direito de o usuário ter conhecimento, independentemente de quaisquer condições ou autorizações, da origem destas e de quaisquer ligações que tenham como destino o seu terminal telefônico.

\section{Os fundamentos das prestadoras para negarem o conhecimento direto ao usuário}

As razões que levam as companhias a negarem ao próprio assinante identificação de chamada para seu aparelho são as seguintes:

A - A Constituição Federal consagra a inviolabilidade do sigilo de dados e das comunicações telefônicas (art. 5o, inc. XII), e estabelece exceção somente mediante autorização judicial. B - A Lei 9296 de 24-07-96, que REGULAMENTA O ART. 5, INCISO XII DA CF, repete a menção exclusiva da autorização judicial.

C - A Lei 9472 de 16 de julho de 1997, que dispõe sobre a ORGANIZAÇÃO DOS SERVIÇOS DE TELECOMUNICAÇÕES, estabelece no seu art. 3ำ, inciso $V$, que o usuário de serviços de telecomunicações tem direito "à inviolabilidade e ao segredo de sua comunicação, salvo nas hipóteses e condições constitucional e legalmente previstas".

D - Na mesma Lei 9472 de 16 de julho de 1997 consta, ainda no mesmo art. 3ำ, inciso VI, o direito do usuário "à não divulgação, caso o requeira, de seu código de acesso".

E - A estas razões se junta aquela advinda das interpretações do SUPREMO TRIBUNAL FEDERAL, o qual veio a considerar como não recepcionado o art. 57, II, letra e da Lei 4717/62 - LEI GERAL DAS TELECOMUNICAÇÕES pela Constituição Federal. Concluiu, portanto, o SUPREMO, que antes da Lei 9296 de 24-07-96, que regulamenta o art. 5으, inciso XII da CF, a quebra de sigilo das comunicações telefônicas não podia ser feita por ausência de lei:

Escuta telefônica autorizada por magistrado, antes do advento da Lei 9296 de 2407-96. Prova Ilícita". - STF (2A Turma, RE 222204/SP, rel. Min. Néri da Silveira, DJU 28-04-00).

Verdade é que o SUPERIOR TRIBUNAL DE JUSTIÇA apontou entendimento discordante, isto é, considerou legal interceptação telefônica autorizada por Juiz, mesmo 
O direito ao conhecimento da origem das ligações telefônicas pelo destinatário, independentemente de qualquer restrição ou autorização judicial

antes da Lei 9296 de 24-07-96. Prova - escuta telefônica - validade porque precedida de autorização judicial $^{3}$

Mais verdadeiro ainda é que o próprio SUPREMO TRIBUNAL FEDERAL, pelo PLENÁRIO, afirmou em medida cuatelar de ação direta de inconstitucionalidade, que a Lei 4117 de 1962 foi recepcionada pela Constituição Federal de 1988, em "seus aspectos básicos e essenciais" - STF, PLENÁRIO, ADI 561-MC/DF, rel. Min. Celso de Mello, j. 23-08-95, DJU 2303-2001.

Muito embora sejam ponderáveis tais razões, pretende-se mediante uma análise mais completa das regras, demonstrar que é direito do usuário destinatário de ligação telefônica ter conhecimento do terminal, do endereço de instalação, da duração da ligação e do titular do terminal de onde se originaram ligações telefônicas.

Importa sublinhar a completa omissão da ANATEL diante da questão, o que implica em dar razão àqueles que entendem que a preocupação da agência é muito mais no sentido de interpretar os interesses das prestadoras. ${ }^{4}$

\section{Dados x comunicações telefônicas}

A quebra de sigilo de dados e das comunicações telefônicas está permitida, conforme os dizeres da própria CF. O art. 50, inciso XII indica que "é inviolável o sigilo da correspondência e das comunicações telegráficas, de dados e das comunicações telefônicas, salvo no último caso,.por ordem judicial, nas hipóteses e na forma que a lei estabelecer para fins de investigação criminal ou instrução processual penal".

Sem embargo, há entendimentos que negam que a CF tenha permitido a quebra de sigilo de dados. ${ }^{5}$ Na realidade, aqueles que negam, interpretam a expressão salvo no último caso, como expressão que se refere exclusivamente a comunicações telefônicas (e não a dados).

O que quer dizer dados?

STJ, 5a Turma, RHC 3612-5, Rel. Assis Toledo, DJU 27-06-94.

4 FARENA, Duciran Van Marsen. O Código de Defesa do Consumidor e os Direitos do Consumidor Usuário do Sistema de Telefonia Fixa. In Revista de Direito do Consumidor 40, out-dez de 2001. São Paulo: Revista dos Tribunais. p. 93-106.

5 GRINOVER, Ada Pellegrini; FERNANDES, Antonio Scarance; GOMES FILHO, Antonio Magalhães. As Nulidades no Processo Penal. 8 ed. São Paulo: Revista dos Tribunais, 2004. p. 212-213. 
Dados, segundo melhor interpretação, envolvem as datas de realizações das chamadas, o número de origem, o número de destino e as respectivas durações. Os dados evidenciam a relação de consumo entre usuário e a prestadora de comunicação telefônica. ${ }^{6}$ Não se está aqui a falar de sigilo das comunicações de dados de outra natureza, que alguns interpretam também serem invioláveis de modo absoluto. ${ }^{7}$

De outro ângulo, também existem os dados cadastrais do usuário. A Lei 9472 de 1607-97, que dispõe sobre a ORGANIZAÇÃO DOS SERVIÇOS DE TELECOMUNICAÇÕES, menciona ser direito do usuário (como não poderia deixar de ser), no art. 3ำ, inciso IX, o "respeito de sua privacidade nos documentos de cobrança e na utilização de seus dados pessoais pela prestadora de serviço".

\section{E o que são comunicações telefônicas?}

Inegavelmente, comunicação telefônica é a conversação entre duas pessoas, cada qual em um aparelho telefônico. Ou, "a comunicação de voz entre duas ou mais pessoas por meio de rede telefônica" 8 .

Pretende-se aqui, chamar especial ATENÇÃO para o seguinte: a Constituição Federal consagra a inviolabilidade de dados e das comunicações, não de modo absoluto, mas admite a interceptação de dados e das comunicações, por ordem judicial, nas hipóteses e na forma que a lei estabelecer para fins de investigação criminal ou instrução processual penal.

Se assim é, num primeiro momento se pode CONCLUIR o seguinte:

A - A LEI 9296 DE 24-07-96 somente regulamenta a interceptação de comunicações telefônicas e admite a interceptação exclusivamente por ordem judicial e exclusivamente quando no interesse da investigação ou processo penal, quando o crime for apenado com reclusão, quando o fato não puder ser provado por outro meio .

B - Não há, portanto, na LEI 9296 DE 24-07-96 qualquer regulamentação ou referência a dados.

C - Fala-se em interceptação telefônica, significando propriamente aqui o conhecimento da conversa entre duas ou mais pessoas por parte de um terceiro, mas não é apropriado falar-

6 FRANCO, Alberto Silva; STOCO, Rui (coord). Leis Penais Especiais e sua Interpretação Jurisprudencial. v. I. 7. ed. São Paulo: Revista dos Tribunais, 2002. p. 1793.

7 AVOLIO, Luiz Francisco Torquato. Provas Ilícitas - Interceptações Telefônicas, Ambientais e Gravações Clandestinas, 3. ed. São Paulo: Revista dos Tribunais, 2003. p. 172

8 NERY JUNIOR, Nelson; NERY, Rosa Maria de Andrade. Código de Processo Civil Comentado e Legislação Processual Civil Extravagante em Vigor. 5. ed. São Paulo: Revista dos Tribunais, 2001. p. 2172. 
O direito ao conhecimento da origem das ligações telefônicas pelo destinatário, independentemente de qualquer restrição ou autorização judicial

se em interceptação de dados telefônicos, pois, o que adequadamente pode ocorrer é a quebra de sigilo de dados.

D - A interceptação telefônica somente pode ser autorizada por Juízo. É reserva jurisdicional (ao lado da autorização de busca e apreensão e da decretação de prisão, com a ressalva quanto a esta da prisão em flagrante). Nem mesmo as Comissões Parlamentares de Inquérito têm direito a decretar a interceptação. Mas a quebra de sigilo de dados e registros telefônicos NÃO é reserva jurisdicional, podendo, como admitido pelo STF, PLENÁRIO ${ }^{9}$, ser promovida pela própria Comissão Parlamentar de Inquérito, conforme decidido expressamente na decisão que tratou dos poderes das Comissões Parlamentares de Inquérito.

\section{A noção de inviolabilidade e os sujeitos abrangidos por ela}

INVIOLABILIDADE "é a prerrogativa ou privilégio outorgado a certas coisas ou pessoas, em virtude do que não podem se atingidas, molestadas ou violadas" ${ }^{10}$.

Considerando o caráter axiológico imanente ao direito, inviolabilidade quer significar a proibição de violar. Violar não tem o sentido de conhecer, de ter contacto. Violar é algo mais. Pode-se dizer que violar é conhecer indevidamente, ter acesso ou ter contacto indevidos.

A inviolabilidade se dirige a certas coisas ou pessoas, mas, logicamente, os sujeitos de tal direito sempre são pessoas.

Assim, os SUJEITOS a favor de quem se dirigem às inviolabilidades são pessoas em certas condições ou com certas qualidades. A inviolabilidade do parlamentar, por exemplo, é dirigida diretamente à figura dos parlamentares, mas tem como objeto suas opiniões, palavras e votos. A inviolabilidade de domicílio tem como sujeito os moradores da casa, mas tem como objeto a casa.

A inviolabilidade de dados e de comunicações telefônicas tem como sujeitos de direito todos aqueles que usam esse meio de comunicação e o objeto da inviolabilidade, obviamente, é a própria comunicação.

9 STF, PLENÁRIO, MS 23652/DF, rel. Min. Celso de Mello, DJU 16-02-01.
10 SILVA, De Plácido e. Vocabulário Jurídico. 8. ed. Rio de Janeiro: Forense, 1984. p. 518. 
Os sujeitos obrigados a atender e cumprir a inviolabilidade são todas as demais pessoas, físicas e jurídicas, inclusive e especialmente as prestadoras de serviços de telefonia, que devem zelar para que as comunicações não sejam violadas por terceiros.

Do que se conclui que se o sujeito é o detentor do direito subjetivo à inviolabilidade, não pode ser figurar como sujeito obrigado a atender e cumprir essa mesma inviolabilidade. Não pode ser ao mesmo tempo o sujeito ativo e passivo da mesma obrigação. Pode-se tomar o dizer de KANT: “o direito é inseparável, segundo o princípio de contradição, da faculdade de obrigar ao que se opõe ao seu exercício” ${ }^{11}$.

O atingir, molestar ou violar, não se referem àqueles que podem, de direito, alcançar a coisa ou a pessoa. A violação é ACESSO INDEVIDO.

\title{
5 As inviolabilidades não são absolutas
}

As inviolabilidades, mesmo que a Constituição Federal não mencione qualquer exceção, não são absolutas.

Tanto assim é que o SUPREMO TRIBUNAL FEDERAL, mesmo constando na CF a inviolabilidade (que seria absoluta) das CORRESPONDÊNCIAS estabeleceu ser regular a interceptação de correspondência pela administração penitenciária, ao fundamento de que:

\begin{abstract}
A administração penitenciária, com fundamento em razões de segurança pública, ou disciplina prisional ou de preservação da ordem jurídica, pode, sempre excepcionalmente, e desde que respeitada a norma inscrita no art. 41, parágrafo único da lei 7210/84, proceder à interceptação da correspondência remetida pelos sentenciados, eis que a cláusula tutelar da inviolabilidade do sigilo epistolar não pode constituir instrumento de salvaguarda de práticas ilícitas ${ }^{12}$
\end{abstract}

Sob outro enfoque, também o SUPERIOR TRIBUNAL DE JUSTIÇA pontua muito bem que a inviolabilidade de correspondência não impede a apreeensão de sua minuta mediante autorização judicial, desde que tal medida impeça consequências maiores em razão de a correspondência servir de meio para afrontar o direito à intimidade e vida privada.

A violação de CORRESPONDÊNCIA, com maltrato à liberdade de pensamento resguardada pela Constituição Federal, somente se concretiza quando se tratar de correspondência fechada. De outro lado, a apreensão de documento, representado

11 KANT, Emmanuel. Doutrina do Direito. Trad. Edson Bini. São Paulo: Icone, 1993. p. 47.

12 STF, $1^{A}$ Turma, HC 70814/SP, rel. Min. Celso de Mello, DJU 24-06-94, p. 16649. 
O direito ao conhecimento da origem das ligações telefônicas pelo destinatário, independentemente de qualquer restrição ou autorização judicial

por minuta de carta já remetida, mediante autorização judicial, não representa afronta ao direito assegurado pelo art. 5o,$X$ da CF (intimidade, vida privada, etc), porque idêntica proteção é reservada à honra das pessoas, não podendo aquela (intimidade) servir de salvaguarda para maltrato a esta (honra) ${ }^{13}$

Também é de ponderar que a inviolabilidade da casa e do sigilo da correspondência e das comunicações telegráficas, de dados e das comunicações telefônicas sustenta-se na inviolabilidade da intimidade, constituindo verdadeira extensão desta última. Ou seja: a fundamentação básica é a defesa da intimidade e vida privada das pessoas.

Mas, o próprio direito à intimidade não constitui direito absoluto, pois, a Lei 9034 de 1995, que dispõe sobre a utilização de meios operacionais para a prevenção e represssão de ações praticadas por organização criminosa, por força da alteração da Lei 10217 de 2001, admite no art. 2o, inciso IV, “a captação e a interceptação ambiental de sinais eletromagnéticos, óticos ou acústicos, e o seu registro e análise, mediante circunstanciada autorização judicial”.

O que se pretende deixar estabelecido são 3 PREMISSAS:

Primeira, que a base da consagração dos direitos às inviolabilidades é o direito à intimidade e vida privada.

Segunda, que o próprio sentido de inviolabilidade, como direito de não ser atingido, molestado ou violado, não se dirige contra todos, sendo óbvio que a inviolabilidade da coisa não pode impedir o acesso dela àquele a quem o princípio visa proteger.

Terceira, que os direitos e garantias às inviolabilidades indicadas na CF não são absolutos. Nem mesmo é absoluto o direito base, que é o direito à intimidade e vida privada. A inviolabilidade é limitada na própria CF ou é quebrada pela interpretação jurisprudencial, em função da ponderação da razoabilidade e proporcionalidade.

\section{Ausência de referência a dados telefônicos na Lei 9296 de 1996}

O STF, por várias vezes, antes da Lei 9296 de 24-07-96 intepretou que a quebra de sigilo das comunicações telefônicas não podia ser feita por ausência de lei. Entendeu que o inciso XII do art. 5o da CF não recepcionou o art. 57, II, e da Lei 4117/62, afirmando ser

13 STJ - RHC improvido, 6 ${ }^{\mathrm{A}}$ Turma, RHC 6719/SP, rel. Min. Fernando Gonçalves, DJU 08-06-98, p. 178. 
necessária a produção de lei para regulamentar a Constituição. Houve entendimento contrário do STJ.

Contudo, foi o próprio SUPREMO TRIBUNAL FEDERAL que expressamente reconheceu o cabimento de quebra de sigilo de dados e registros telefônicos. E o fez, pelo PLENÁRIO, quando discutiu a validade de atos das Comissões Parlamentares de Inquérito:

[...] A QUEBRA DO SIGILO CONSTITUI PODER INERENTE À COMPETÊNCIA INVESTIGATÓRIA DAS COMISSÕES PARLAMENTARES DE INQUÉRITO. O sigilo bancário, o sigilo fiscal e o SIGILO TELEFÔNICO (sigilo este que incide sobre os DADOS/REGISTROS TELEFÔNICOS e que não se identifica com a inviolabilidade das comunicações telefônicas) - ainda que representem projeções específicas do direito à intimidade fundado no art. 5o, X da Carta Política - não se revelam oponíveis, em nosso sistema jurídico às Comissões Parlamentares de Inquérito, ei que $o$ ato que lhes decreta a quebra traduz natural derivação dos poderes de investigação que foram conferidos pela própria Constituição da República aos órgãos de investigação parlamentar $[\ldots]^{14}$.

Note-se a postura do SUPREMO TRIBUNAL FEDERAL:

Primeiro o STF, inclusive pelo PLENÁRIO ${ }^{15}$, entendia que a ausência de lei específica a regulamentar o art. 5ำ XII da CF impedia a interceptação telefônica.

Com o advento da Lei 9296 de 24-07-96 a exigência veio a ser atendida, tornandose possível a violação de comunicações telefônicas, mediante a interceptação. Mas, a Lei 9296 de 24-07-96 não contém qualquer referência a dados e registros. Como o STF, inclusive através do PLENÁRIO havia sustentado ser ilegal a própria interceptação, por falta de lei regulamentadora, como ainda não existe esta menção na lei regulamentadora, isto tornaria os dados de comunicações telefônicas insuscetíveis de quebra de sigilo ou insuscetíveis de violação.

Mas, o próprio STF, pelo PLENÁRIO, admitiu e reconheceu a possibilidade de quebra de sigilo telefônico incidente sobre dados e registros.

EM RESUMO:

Mesmo tendo o STF entendido que a Lei 4117/62 não fora recepcionada pela CF, e somente o advento da Lei 9296/96 é que tornaria legal a interceptação telefônica, continuou 
O direito ao conhecimento da origem das ligações telefônicas pelo destinatário, independentemente de qualquer restrição ou autorização judicial

a entender possível a quebra de dados de sigilos telefônicos, embora a Lei 9296/96 nada refira sobre quebra de sigilo de dados telefônicos.

\section{A decisão do plenário do STF amplificativa da Lei 9296 de 24-07-96}

A LEI 9296 de 24-07-96 ao regulamentar a interceptação telefônica mediante "autorização judicial para fins de investigação criminal ou instrução processual penal", estabeleceu alguns pressupostos para tornar possível a autorização judicial. Permitimo-nos destacar dois pressupostos que interessam a esta análise:

a) Não cabimento da interceptação telefônica quando a infração é punida com detenção, no máximo.

b) O PRAZO para escuta é de 15 dias prorrogáveis por igual prazo, se necessário. Cabe à autoridade policial conduzir os procedimentos de interceptação, dando ciência ao Ministério Público, que poderá acompanhá-la.

O SUPREMO TRIBUNAL FEDERAL, pelo PLENÁRIO, em 16-set- 04, quando denegou o HABEAS CORPUS HC 83515/RS, por 8 a 1, interpretou que:

- a interceptação requerida após apuração de CPI estadual, não foi a primeira diligência feita. Assim, o STF afastou a argumentação da defesa de que a quebra do sigilo deu-se pelo juiz antes da instauração do inquérito policial;

- o prazo de renovação das interceptações (entre abril e outubro de 2001) pode exceder ao previsto na Lei 9296/96, reconhecendo que as renovações foram fundamentadas devidamente;

- não é necessária a transcrição completa das conversas a cada pedido de renovação de autorização, dado que foi disponibilizada transcrição completa aos réus, assim que foi encerrado o sigilo;

- ser válida a utilização das gravações para provar outros crimes quer sujeitos a reclusão quer sujeitos a detenção, crimes estes que não haviam gerado o pleito de gravação, pois quando tais crimes forem conexos, podem e devem ser levados em consideração.

Note-se então, que o SUPREMO TRIBUNAL FEDERAL admitiu várias renovações e que as gravações podem ser utilizadas para prova de outros crimes conexos, mesmo que não sujeitos a reclusão. Note-se, ademais, que o SUPREMO TRIBUNAL FEDERAL, pelo PLENÁRIO, deu elasticidade e extensão à Lei 9296/96. 
O que se pretende sublinhar é que é sempre possível a interpretação ampliativa da lei ou mesmo da Constituição Federal.

O STF, conforme demonstrado, interpretou propter legem, para não dizer ultra legem a própria Lei. Na realidade, o STF deu aplicabilidade, sentido práticointegrativo à lei. Não há dúvida do acerto de tal entendimento, haja vista que a interceptação telefônica autorizada judicialmente há de servir para desvendar tudo o que por meio dela se descobrir, abrangendo inclusive terceiros não mencionados como suspeitos inicialmente ${ }^{16}$. De se sublinhar que o SUPREMO TRIBUNAL FEDERAL rechaça as provas ilícitas em face do acatamento da fruit of poisonnous tree, mas é mais conforme com o nosso direito o acatamento do princípio da proporcionalidade e a ponderação entre o interesse violado e o interesse público -(apuração do fato e responsabilização dos agentes). ${ }^{17}$

\section{0 sigilo é para terceiros não para os protagonistas}

Mesmo quanto às comunicações telefônicas não se fala em interceptação quanto a A e B, protagonistas da comunicação. Apenas um terceiro pode interceptar as comunicações. A inviolabilidade se direciona contra todos os outros, exceto A e B.

Tanto assim é que a gravação unilateral é considerada constitucional e legal, podendo ser usada como prova lícita. A única restrição à utilização desta gravação é a quebra do direito à intimidade:

HABEAS CORPUS. Utilização de gravação de conversa telefônica feita por terceiro com autorização de um dos interlocutores sem o conhecimento do outro, quando há, para essa utilização, excludente da antijuridicidade.Afastada a ilicitude de tal conduta - a de, por LEGÍTIMA DEFESA, fazer gravar e divulgar conversa telefônica ainda que não haja o conhecimento do terceiro que está praticando crime - é ela, por via de conseqüência, lícita e, também consequentemente, essa gravação não pode ser tida como prova ilícita, para invocar-se o artigo 5o LVI da Constituição, com fundamento em que houve violação da intimidade (art. 5o, X da Carta Magna). Habeas corpus indeferido ${ }^{18}$.

A gravação feita por um dos seus interlocutores, exclui a ilicitude do meio de obtenção da prova. O Supremo Tribunal Federal, nesta esteira, tem entendido que não há qualquer violação constitucional do DIREITO DE PRIVACIDADE quando a vítima grava diálogo com qualquer tipo de criminoso (HC 75.338/RJ, rel. Min.

16 PEDROSO, Fernando de Almeida. Processo Penal - O direito de Defesa: Repercussão, Amplitude e Limite. 3. ed. São Paulo: Revista dos Tribunais, 2001. p. 407.

17 GUARAGNI, Fábio André. Prova llícita e Princípio da Proporcionalidade: o Tratamento no Processo Penal Brasileiro. In Cadernos do Ministério Público do Paraná, v. 3, no 9, nov/2000, p. 69-84.

18 O STF, 1A turma, no HC 74.678-1 de SP, Min. Moreira Alves, j. em 10-06-97, no DJU 15-08- 97, p. 37036 
O direito ao conhecimento da origem das ligações telefônicas pelo destinatário, independentemente de qualquer restrição ou autorização judicial

Nelson Jobim, DJU 25-09-98). Este, também é o entendimento jurisprudencial adotado por esta Egrégia Corte (RHC 7216/SP, rel. Min. Edson Vidigal, DJU 28-04$98)^{19}$

Portanto, não há propriamente direito à inviolabilidade por parte dos envolvidos. $A$ lattere relembre-se a liberdade de manifestação de pensamento e a vedação de anonimato (art. 5ㅇ, IV da CF), que também se traduz como uma garantia da eficácia do direito à privacidade, vislumbrado no próprio inciso $\mathrm{X}$ do art. 5 o da $\mathrm{CF}^{20}$.

Se nem mesmo se entende constituir violação a gravação unilateral de conversa telefônica, com maior razão, não há violação de dados e registros telefônicos no fato de um dos protagonistas conhecer os dados e registros. Se A liga para B, evidentemente que nem $A$ nem $B$ têm qualquer obrigação de sigilo desses dados. Ao contrário: $B$ tem direito de saber de onde provém a ligação para seu terminal, qual o titular desse terminal e quantos minutos durou a ligação.

Estes dados podem ser obtidos diretamente pelo próprio receptor de ligação (caso de instalação dos chamados binas), mas também é OBRIGAÇÃO da prestadora de serviço como corolário do princípio da eficiência da prestação de serviços (art. 6ำ, X do CÓDIGO DE DEFESA DO CONSUMIDOR).

Obviamente, quando A liga para B, não há que falar em sigilo por parte de A.

Em resumo:

Só se fala em inviolabilidade de dados para terceiros e nunca para os protagonistas. O direito à intimidade (ou privacidade, como alguns preferem) que sustenta as inviolabilidades, determina que o titular desse direito possa escolher divulgá-los ou não ${ }^{21}$, repita-se, porque são os titulares do direito.

\section{A validade da Lei 4117 de 1962 em matéria de dados e registros telefônicos}

Conforme exposto, os dados e registros bancários podem ser identificados: a) para terceiros, em investigação, mediante autorização judicial ou pelas CPIs; b) para os próprios protagonistas, porque não alcançados pela proibição da violação.

\footnotetext{
19 STJ 5a Turma, RHC 10429/MG, rel. Min. Jorge Scartezzini, DJU 20-08-01, p. 489

20 SILVA, José Afonso da. Curso de Direito Constitucional Positivo. 22. ed. São Paulo: Malheiros, 2003. p. 244.

21 TAVARES, André Ramos. Curso de Direito Constitucional. São Paulo: Saraiva, 2002. p. 437.
} 
Está constatado que a Lei 9696/96 ao regulamentar o inciso XII, parte final, do art. 5o da CF, tratou somente da interceptação telefônica, que é a violação por parte de um terceiro, de conversa telefônica entre outras pessoas.

Logo, a dedução lógica é que a Lei que fundamenta a violação dos dados telefônicos é a Lei no. 4117 de 1962, que no seu art. 57, declara que:

Art. 57 - Não constitui violação de telecomunicação:

II - o conhecimento dado:

a) ao destinatário da telecomunicação ou a seu representante legal.

Observe-se que quando o SUPREMO TRIBUNAL FEDERAL afirmou que esta Lei 4117 de 1962, não fora recepcionada pela Constituição Federal, referira-se o SUPREMO que não fora recepcionada quanto ao regramento de interceptação de comunicação telefônica, EXCLUSIVAMENTE.

E isto se deduz porque, não houve lei nova que regulasse integralmente a matéria da lei anterior. E a recepção da Lei 4117 de 1962 pela Constituição Federal de 1988, em seus aspectos básicos e essenciais, foi confirmada pelo SUPREMO TRIBUNAL FEDERAL, PLENÁRIO, na já mencionada ADI 561-MC/DF. Ao contrário, a Lei 9296/96 nada contém sobre dados telefônicos e, portanto, a Lei 4117 de 1965 continua válida e a regular tal matéria.

Veja-se que a gravação unilateral de conversa telefônica feita por um dos interlocutores é considerada legal. Com maior razão, identificar o número de telefone é bem menos suscetível de se poder considerar violação à intimidade do que a gravação.

Ao destinatário a prestadora deve dar todas as informações, especialmente se pedidas por ele, mesmo que não se refiram a crime. Cabe acrescentar que a prestadora deve dotar-se de técnica para identificar inclusive os telefones cuja numeração não aparece em equipamentos como o bina.

É que, em face da ponderação dos interesses envolvidos, deve prevalecer o interesse de quem recebe as ligações telefônicas, em relação ao outro interesse chancelado pela Lei 9472/97 que dispõe sobre a ORGANIZAÇÃO DO SERVIÇOS DE TELECOMUNICAÇÕES, que consagra no art. 3ำ, inciso $\mathrm{VI}$, o direito do usuário "à não divulgação, caso o requeira, de seu código de acesso". 
O direito ao conhecimento da origem das ligações telefônicas pelo destinatário, independentemente de qualquer restrição ou autorização judicial

O direito à não divulgação do código de acesso: a) refere-se à divulgação geral em listas telefônicas e outros meios; b) somente se refere ao código de acesso, não alcançando a identificação do titular do telefone de onde provém ligações.

\section{Conclusão}

A - A Constituiçâo Federal no art. 5ㅇ, XII refere a inviolabilidade dos dados e comunicações telefônicas, SALVO por ordem judicial, nas hipóteses e na forma que a lei estabelecer para fins de investigação criminal ou instrução processual penal.

B - Não se deve confundir interceptação de comunicação telefônica com sigilo de dados ou registros telefônicos. O STF, pelo PLENÁRIO, quando decidiu a respeito dos poderes das Comissões Parlamentares de Inquérito distinguiu um e outros. Os dados $e$ registros telefônicos referem-se tão somente à identificação de ligações entre numeros telefônicos, a respectiva data e hora e a respectiva duração. A interceptação é reserva de jurisdição. O sigilo de dados e registros telefônicos pode ser quebrado diretamente pelas próprias CPIs.

C - O conhecimento de dados e registros telefônicos é direito do protagonista, obrigação das prestadoras de serviços telefônicos, dispensando qualquer autorização judicial, dispensando mesmo indicação de existência de possível crime, entre outros motivos porque a inviolabilidade não se dirige contra quem é titular de direito que ela visa proteger e não há ofensa à intimidade oponível contra quem é destinatário de ligação telefônica.

\section{Referências}

AVOLIO, Luiz Francisco Torquato. Provas Ilícitas - Interceptações Telefônicas, Ambientais e Gravações Clandestinas, 3. ed. São Paulo: Revista dos Tribunais, 2003.

FARENA, Duciran Van Marsen. O Código de Defesa do Consumidor e os Direitos do Consumidor Usuário do Sistema de Telefonia Fixa. Revista de Direito do Consumidor, São Paulo, 40, p. 93-106, out./dez. 2001.

FRANCO, Alberto Silva; STOCO, Rui (Coord). Leis Penais Especiais e sua Interpretação Jurisprudencial. 7. ed. São Paulo: Revista dos Tribunais, 2002.v. 1. 
GUARAGNI, Fábio André. Prova llícita e Princípio da Proporcionalidade: o Tratamento no Processo Penal Brasileiro. Cadernos do Ministério Público do Paraná, v. 3, n. 9, p. 69-84, nov. 2000.

GRINOVER, Ada Pellegrini; FERNANDES, Antonio Scarance; GOMES FILHO, Antonio Magalhães. As Nulidades no Processo Penal. 8. ed. São Paulo: Revista dos Tribunais, 2004.

KANT, Emmanuel. Doutrina do Direito. Trad. Edson Bini. São Paulo: Icone, 1993.

NERY JUNIOR, Nelson; NERY, Rosa Maria de Andrade. Código de Processo Civil Comentado e Legislação Processual Civil Extravagante em Vigor. 5. ed. São Paulo: Revista dos Tribunais, 2001.

PEDROSO, Fernando de Almeida. Processo Penal - O direito de Defesa: Repercussão, Amplitude e Limite. 3. ed. São Paulo: Revista dos Tribunais, 2001.

SILVA, De Plácido e. Vocabulário Jurídico. 8. ed. Rio de Janeiro: Forense, 1984.

SILVA, José Afonso da. Curso de Direito Constitucional Positivo. 22. ed. São Paulo: Malheiros, 2003.

TAVARES, André Ramos. Curso de Direito Constitucional. São Paulo: Saraiva, 2002. 